\title{
The north-east Baffin Bay region, offshore Greenland - a new frontier petroleum exploration region
}

\author{
Ulrik Gregersen
}

In recent years the Arctic has come into focus for hydrocarbon exploration, and areas offshore both West and East Greenland have been evaluated as promising frontier hydrocarbon provinces. Seven hydrocarbon exploration and exploitation licenses were awarded in 2007-2008 offshore the Disko-Nuussuaq region (Fig. 1), and two more have been awarded in the open-door region offshore south-western Greenland. In 2007, an extensive amount of new seismic and aero- magnetic data was acquired by the TGS-NOPEC Geophysical Company in the north-eastern Baffin Bay region.

Geophysical mapping has been initiated by the Geological Survey of Denmark and Greenland (GEUS) in the Melville Bugt region offshore North-West Greenland (Fig. 1) with the purpose of evaluating the hydrocarbon prospectivity. Initial interpretation of seismic and gravity data suggests the presence of deep sedimentary basins separated by structural highs.

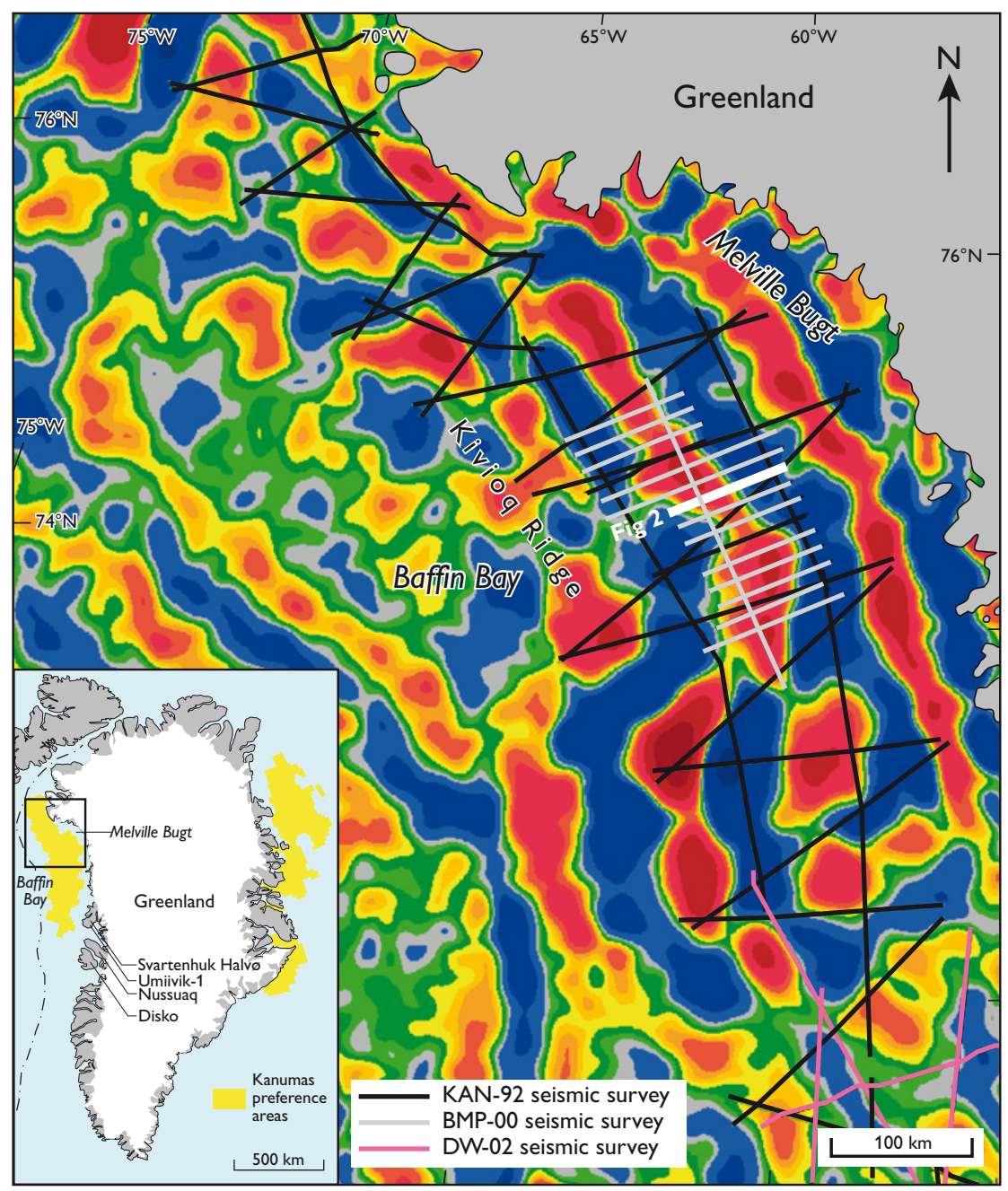

Fig. 1. Gravity map (100 km filtered bouguer gravity data) of the study region, showing the seismic grid. The location of the seismic line shown in Fig. 2 is indicated. Large areas with marked high gravity values (red) often indicate structural highs, whereas areas with low values (blue) mostly indicate deep sedimentary basins. Most basins and marked highs indicated by gravity data are confirmed by seismic data (Fig. 2). The gravity data are public domain data from the Danish National Space Center and have been filtered by GEUS. 


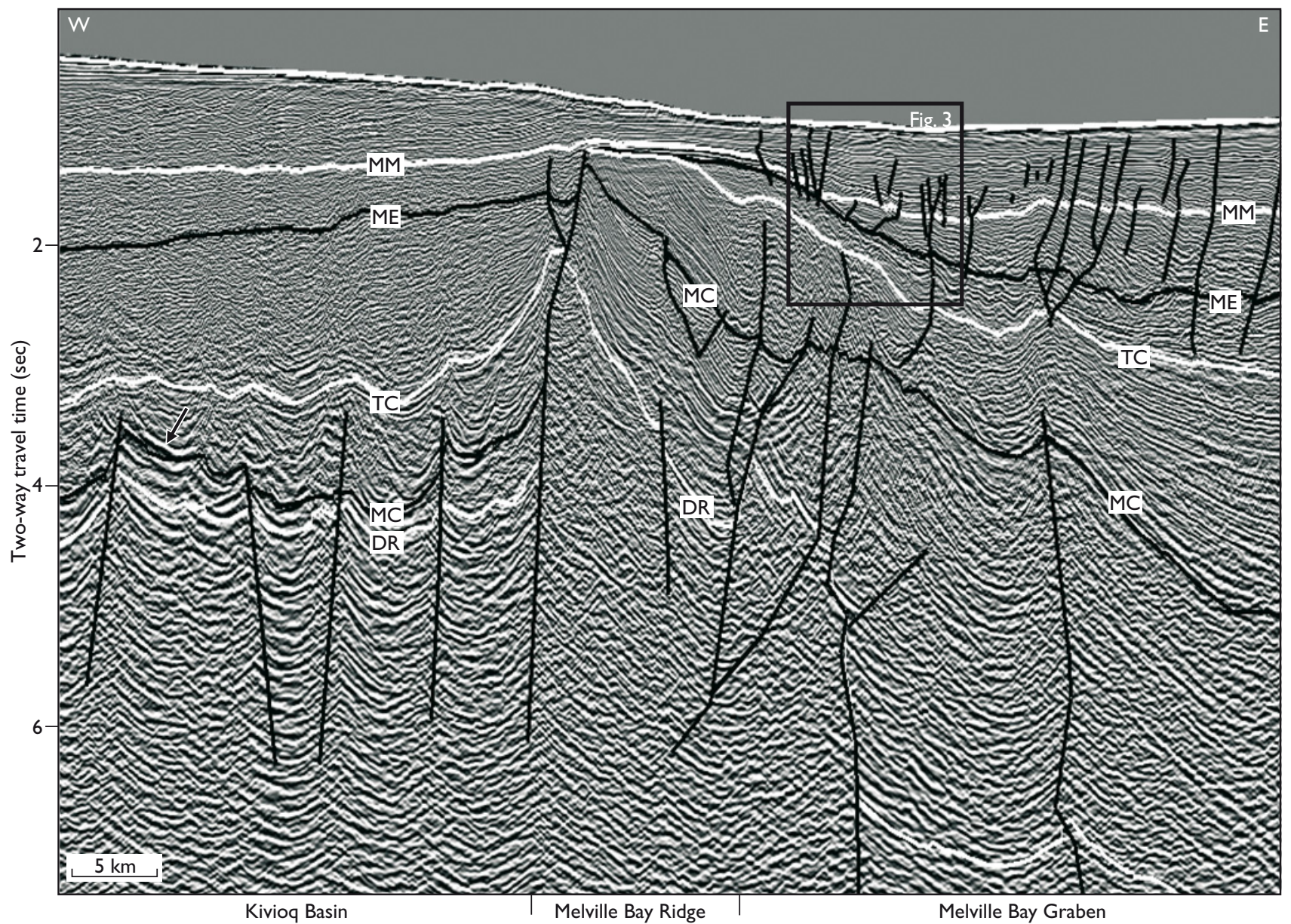

Fig. 2. Seismic section BMP00-209, Melville Bugt region, eastern Baffin Bay, illustrating the structural elements (for location of line, see Fig. 1). Intervals below the 'mid-Cretaceous' (MC) and just below and above the 'top Cretaceous' (TC) horizons may, by analogy with surrounding regions, contain reservoir levels. Structural closures are present at levels near the 'mid-Cretaceous' and the 'top Cretaceous' horizons in the basin and the graben areas. Cretaceous structures are locally affected by Palaeogene tectonic reactivation indicated by convex flexures above the TC horizon. The 'mid-Eocene' (ME) and the 'mid-Miocene' (MM) horizons truncate structures, especially over the Melville Bay Ridge, and the horizons are locally affected by Neogene faulting. Local U-shaped marked reflections with high amplitudes at the 'mid-Cretaceous' horizon may indicate intrusions, e.g. in the Kivioq Basin (arrowed). The succession below the 'deep reflection' (DR) horizon loses seismic reflector continuity, and probably reflects mostly the crystalline basement. Local scattered, low continuity reflections at the DR horizon may result from deeply buried Proterozoic to Palaeozoic sediments and volcanics, probably comparable to some of those known north of the study area. The frame marks the location of Fig. 3.

Geological information on source rock, reservoir rock and seal intervals from surrounding regions suggest that the Melville Bugt region is likely to have a significant petroleum potential. The study is based on public domain magnetic and gravity data, and all proprietary and public 2-D seismic data (Fig. 1) acquired before 2003. Seismic horizons from the 'seismic basement' to 'base Quaternary' are being interpreted regionally. Based on the seismic interpretation, a structural element map, depth-structure maps and isopach maps will be produced in order to assess the prospectivity of the Melville Bugt region.

\section{Structures and basin development}

Interpretations of structures and basin development are mainly based on seismic data supplemented by gravity and magnetic data. Because no wells have been drilled in eastern Baffin Bay, interpretations of the geological development and petroleum prospectivity are based partly on correlations to wells farther south and partly on the onshore geology of the surrounding region. The mapping and regional analyses show deep basins and mainly north-north-west-trending major structural highs (Figs 1,2). The Melville Bugt region is proba- 
Fig. 3. Detail of the seismic section in Fig. 2 showing abnormal seismic amplitude values (arrowed), interpreted as possible 'bright spots'. bly characterised by continental crust, whereas oceanic crust may be present farther west, in the central part of Baffin Bay (Whittaker et al. 1997; Oakey 2005). The highs and basins in the Melville Bugt region probably developed during several phases of mainly Cretaceous to Paleocene rifting and compressional strike-slip related Palaeogene tectonism.

The first rift phase probably occurred during Early to midCretaceous time and resulted in mainly extensional faulting that created the two major structural highs in the region, the Melville Bay Ridge and the Kivioq Ridge, and some normal faults in the adjacent grabens (Fig. 2). The second rift phase occurred in Late Cretaceous and possibly in early Paleocene time and resulted in normal faulting, partly reactivating earlier Cretaceous faults. During the Palaeogene, flexures and thrust faults developed related to compressional tectonics, which affected especially the central and northern parts of the region. The Melville Bay Ridge was uplifted during the Late Cretaceous and Palaeogene (Fig. 2). The boundary fault east of the Melville Bay Graben was active at least during the Cretaceous and early Palaeogene, giving way to major graben subsidence. In the graben, more than $12 \mathrm{~km}$ of sediments accumulated that probably comprise mainly Mesozoic and Cenozoic deposits. In the lower part of the graben, some Palaeozoic and Proterozoic deposits similar to those known in North-West and North Greenland may be present (Peel \& Sønderholm 1991; Dawes 1997).

A more than $1.3 \mathrm{~km}$ thick succession of Palaeogene basalts occurs in the southern part of the region and thickens southeastwards towards Svartenhuk Halvø. On Svartenhuk Halvø, Nuussuaq and Disko a thick Palaeogene basalt succession is exposed (Larsen \& Pulvertaft 2000; Pedersen et al. 2006), and thick, tilted basalt successions are interpreted to extend out onto the adjacent offshore area (Skaarup \& Pulvertaft
2007). Offshore, the basalts occur in the upper part of some fault blocks that are on-lapped by subsequent deposits below the suggested mid-Eocene horizon, indicating a mainly early Eocene age of faulting and tilting of the blocks, which is also described by Skaarup \& Pulvertaft (2007). Deposition of thick sedimentary successions took place during the Late Cretaceous and in parts of the Palaeogene. A major unconformity has been recognised at a mid-Eocene level both in the Baffin Bay region (Fig. 2) and offshore West Greenland (Dalhoff et al. 2003). Neogene deposition is characterised by westwards and southwards prograding depositional systems, as also seen farther south offshore West Greenland (Dalhoff et al. 2003).

\section{Prospectivity}

The Melville Bugt region in eastern Baffin Bay probably has a considerable hydrocarbon potential. Major structures have been located at a suggested mid-Cretaceous level (Fig. 2), some with large structural closures at depths of $c .1-4 \mathrm{~km}$. Most of the structures have an attractive combination of size, short distance to potential mature source kitchens and a thick overburden. Several potential reservoir rock levels may be present if Cretaceous and Palaeogene sand dominated units equivalent to those found farther south offshore and onshore West Greenland are also present here (Dalhoff et al. 2003; Scherstén \& Sønderholm 2007). 
The deep basins of the Melville Bugt region contain thick successions of sedimentary rocks that may include prolific source rocks. Several indications of an active hydrocarbon system with mature source rocks are known from Canada and western Greenland. In the Arctic islands of Canada these comprise exposed oil-prone source rocks of the Kanguk Formation (Núñez-Betelu et al. 1993) and the Scott Trough oil seep (MacLean et al. 1981).

In West Greenland the presence of mature source rocks is proven by oil seeps onshore Nuussuaq, Disko and Svartenhuk Halvø (Bojesen-Koefoed et al. 1999, 2007). Oil and gas have been encountered in boreholes on Nuussuaq and Svartenhuk Halvø (e.g. wet gas in the Umiivik-1 borehole; Dam et al. 1998). 'Bright spots' (Fig. 3) and other hydrocarbon indicators related to structural closures or faults in the Melville Bugt region also suggest an active hydrocarbon system. A 'bright spot' is a type of hydrocarbon indicator that may point to, for example, gas in sands. Potential mid-Cretaceous source intervals may, as farther south, be in the 'late oil window' (Gregersen et al. 2007), whereas the more deeply buried parts may be in the 'gas window'. The distances from the source kitchens to the mapped structures are mostly less than $50 \mathrm{~km}$. The Cenozoic sediment cover generally exceeds 900 $\mathrm{m}$ over the Cretaceous structures. The potential seal sections of Late Cretaceous and Palaeogene ages are probably dominated by mudstones with local sands as known from outcrops and a few wells farther south (Dalhoff et al. 2003; Gregersen et al. 2007).

The seismic data from the eastern Baffin Bay region (BMP-00 from the year 2000) have increased our knowledge about the main structures and faults and have facilitated the interpretation of the basins, but new data are needed to increase our understanding of the geology and prospectivity of the region.

\section{References}

Bojesen-Koefoed, J.A., Christiansen, F.G., Nytoft, H.P. \& Pedersen, A.K. 1999: Oil seepage onshore West Greenland: evidence of multiple source rocks and oil mixing. In: Fleet, A.J. \& Boldy, S.A.R. (eds): Petroleum geology of Northwest Europe: Proceedings of the 5 th conference, 305-314. London: Geological Society.
Bojesen-Koefoed, J.A., Bidstrup, T., Christiansen, F.G., Dalhoff, F., Gregersen, U., Nytoft, H.P., Nøhr-Hansen, H., Pedersen, A.K. \& Sønderholm, M. 2007: Petroleum seepages at Asuk, Disko, West Greenland - implications for regional petroleum exploration. Journal of Petroleum Geology 30, 219-236.

Dalhoff, F., Chalmers, J.A., Gregersen, U., Nøhr-Hansen, H., Rasmussen, J.A. \& Sheldon, E. 2003: Mapping and facies analysis of Paleocene Mid-Eocene seismic sequences, offshore southern West Greenland. Marine and Petroleum Geology 20, 935-986.

Dam, G., Nøhr-Hansen, H., Christiansen, F.G., Bojesen-Koefoed, J.A. \& Laier, T. 1998: The oldest marine Cretaceous sediments in West Greenland (Umiivik-1 borehole) - record of the Cenomanian-Turonian anoxic event? Geology of Greenland Survey Bulletin 180, 128-137.

Dawes, P.R. 1997: The Proterozoic Thule Supergroup, Greenland and Canada: history, lithostratigraphy and development. Geology of Greenland Survey Bulletin 174, 150 pp.

Gregersen, U., Bidstrup, T., Bojesen-Koefoed, J.A., Christiansen, F.G., Dalhoff, F. \& Sønderholm, M. 2007: Petroleum systems and structures offshore central West Greenland: implications for hydrocarbon prospectivity. Geological Survey of Denmark and Greenland Bulletin 13, 25-28. Larsen, J.G. \& Pulvertaft, T.C.R. 2000: The structure of the Cretaceous-Palaeogene sedimentary-volcanic area of Svartenhuk Halvø, central West Greenland. Geology of Greenland Survey Bulletin 188, 40 pp.

MacLean, B., Falconer, R.K. \& Levy, E.M. 1981: Geological, geophysical and chemical evidence for natural seepage of petroleum off the northeast coast of Baffin Island. Bulletin of Canadian Petroleum Geology 29, 75-95.

Núñez-Betelu, L.K, Riediger, C.L. \& Hills, L.V. 1993: Rock-eval analysis of the Cretaceous Bastion Ridge and Kanguk Formations, Axel Heiberg and Ellesmere Islands, Canadian Arctic Archipelago. Abstract (A-78), Annual Meeting of the Geological Association of Canada, Edmonton.

Oakey, G.N. 2005: Cenozoic evolution and lithosphere dynamics of the Baffin Bay - Nares Strait region of Arctic Canada and Greenland, 233 pp. Unpublished Ph.D. thesis, Vrije Universiteit, Amsterdam, The Netherlands

Pedersen, A.K., Larsen, L.M., Pedersen, G.K. \& Dueholm, K.S. 2006: Five slices through the Nuussuaq Basin, West Greenland. Geological Survey of Denmark and Greenland Bulletin 10, 53-56.

Peel, J.S. \& Sønderholm, M. (eds) 1991: Sedimentary basins of North Greenland. Bulletin Grønlands Geologiske Undersøgelse 160, 164 pp.

Scherstén, A. \& Sønderholm, M. 2007: Provenance of Cretaceous and Paleocene sandstones in the West Greenland basins based on detrital zircon dating. Geological Survey of Denmark and Greenland Bulletin 13, 29-32.

Skaarup, N. \& Pulvertaft, T.C.R. 2007: Aspects of the structure on the coast of the West Greenland volcanic province revealed in seismic data. Bulletin of the Geological Society of Denmark 55, 65-80.

Whittaker, R.C., Hamann, N.E. \& Pulvertaft, T.C.R. 1997: A new frontier province offshore northwest Greenland; structure, basin development, and petroleum potential of the Melville Bay area. American Association of Petroleum Geologists Bulletin 81, 978-998. 